\title{
Neurosarcoidosis Associated with Psychiatric Symptoms: Case Report
}

\section{Neurossarcoidose associada com sintomas psiquiátricos: relato de caso}

\author{
Maick Wilen Fernandes Neves ${ }^{1}$ Paulo Henrique Pires de Aguiar ${ }^{2}$ Telmo Augusto Barba Belsuzarri ${ }^{3}$ \\ Wolnei Marques Zeviani ${ }^{3}$ João Flavio de Araújo Mattos ${ }^{3}$ Juliano Nery Navarro ${ }^{3}$ \\ Renata de Melo Braga Marques ${ }^{4,5}$ Letícia Marissol de Souza Francisco ${ }^{4}$
}

${ }^{1}$ Pontifícia Universidade Católica de Campinas (PUC-Campinas),

Address for correspondence Maick Wilen Fernandes Neves, Medical

Campinas, São Paulo, Brazil

2 Department of Neurosurgery, Hospital Santa Paula, São Paulo, Resident, Pontifícia Universidade Católica de Campinas, Campinas, São Paulo, Brazil (e-mail: maickfernandes@gmail.com).

São Paulo, Brazil

${ }^{3}$ Department of Neurosurgery, Hospital Celso Pierro, PUC Campinas,

Campinas, São Paulo, Brazil

${ }^{4}$ Hospital Celso Pierro, Pontifícia Universidade Católica de Campinas

(PUC-Campinas), Campinas, São Paulo, Brazil

${ }^{5}$ Centro de Atenção Integral à Saúde da Mulher (Caism), Universidade

Estadual de Campinas (Unicamp), Campinas, São Paulo, Brazil

Arq Bras Neurocir 2017;36:185-189.

\section{Abstract \\ Keywords \\ - sarcoidosis \\ - neurosarcoidosis \\ - psychiatric manifestations \\ - pathology}

\section{Resumo}

Background Sarcoidosis is a granulomatous disease predominant in women and black men that has inflammatory origin of unknown etiology; neurosarcoidosis is a rare and critical presentation of the disease.

Case description A 26-year-old black female presented frontal headache for 1 year, as well as behavioral and mood changes for 15 days. Skull tomography and nuclear magnetic imaging of the skull revealed damaged meninges, a right frontal bone lesion, and an intraparenchymal contrast-enhancing lesion. Screening with computed tomography (CT) scans was performed, and it showed signs of bronchiectasis in the lower third of the right lung, but it was asymptomatic. The biopsy showed signs of reactional lesion with the presence of non-caseating granulomas. After the treatment with corticosteroids, the patient presented progressive improvement.

Conclusions Neurosarcoidosis is a rare and critical pathology of sarcoidosis that presents a lytic bone lesion and clinical psychiatric symptoms; neurosarcoidosis is also rare in the literature.

Introdução A sarcoidose é uma doença granulomatosa de origem inflamatória de etiologia desconhecida, predominante em mulheres e negros, sendo a neurosarcoidose uma apresentação da doença rara relacionada a gravidade.

Relato de Caso Paciente com 26 anos, negra, apresenta quadro cefaleia frontal ha 1 ano e há 15 dias apresentando sinais de alterações de comportamento e humor. received

April 15, 2017

accepted

July 18, 2017

published online

August 24, 2017
DOI https://doi.org/

10.1055/s-0037-1606290. ISSN 0103-5355.
Copyright $\odot 2017$ by Thieme Revinter

Publicações Ltda, Rio de Janeiro, Brazil
License terms

(c) (i) $\ominus$ (\$) 


$$
\begin{aligned}
& \text { Palavras-chave } \\
& \text { - sarcoidose } \\
& \text { - neurosarcoidose } \\
& \text { - manifestações } \\
& \text { psiquiátricas } \\
& \text { - patologia }
\end{aligned}
$$

Tomografia de crânio e Ressonância nucelar magnética de crânio que evidenciaram lesão óssea frontal direita, comprometimento meninges e lesão intraparenquimatosa captante de contraste. Realizado screening com tomografias que evidenciaram sinais de bronquiectasia em terço inferior pulmão direito, assintomática. Biopsia indicando sinais de lesão reacional com presenças de granulomas não caseosos, Após a manutenção da corticoterapia, a paciente apresentou melhora progressiva.

Conclusões A neurosarcoidose é uma patologia grave e rara da sarcoidose, nesse caso apresenta uma lesão óssea lítica e sintomas psiquiátricos, apresentação rara na literatura.

\section{Introduction}

Sarcoidosis is a multisystem inflammatory disease of unknown etiology in which non-caseating granulomas are found in the affected organs (mainly the lungs, the skin, and the lymph nodes). ${ }^{1}$ The incidence of sarcoidosis in Brazil is of 10/100,000 inhabitants, and the worldwide incidence of neurosarcoidosis is estimated to be $\sim 0.2 / 100,000$ inhabitants. The incidence of the disease is higher among women and black men aged between 20 and 40 years, and it is rarely seen in children. ${ }^{1-5}$

A genome study has shown that human leukocyte antigens (HLAs) DRB1 and DQB1 are risk factors for the association with sarcoidosis. ${ }^{6,7}$ Neurosarcoidosis is rare, and 5-15\% of the patients with sarcoidosis will have the central nervous system, brain, and spine cord affected; among these, 50\% will present symptoms. ${ }^{8-10}$

\section{Case Report}

A 26-year-old black female patient presented frontal headache for 1 year, as well as sadness, tearfulness, and decreased appetite for the previous 15 days. She sought medical attention and was treated with risperidone and clonazepam, but there was no clinical improvement. During the neurological examination, she presented time and space disorientation, so a skull tomography (-Fig. 1) was requested, evidencing hypodensity and loss of cortical-subcortical differentiation in the right frontal region. Following the investigation, nuclear magnetic resonance imaging (MRI) was used, which revealed a meningeal lesion with infiltration of the cerebral parenchyma associated with lytic lesions in the cranial calotte (-Fig. 2 ).

Thoracic and total abdominal screening tests were performed, and showed a focal lesion $(1.6 \mathrm{~cm})$ in the spleen with late uptake compatible with hemangioma and focal bronchiectasis in the lower lobe of the left lung (-Fig. $\mathbf{3}$ ), as well as bilateral subsegmental atelectasis. The echocardiogram and cerebrospinal fluid (CSF) examination were normal.

Meningeal and brain tissue biopsies were performed using a surgery approach, with supraorbital access and right supraciliary incision. During this period, the patient was treated with corticoids due to cerebral edema and mass effect; she showed an improvement in the signs and symptoms.

The anatomopathological analysis showed a small amount of granulomas in the bone region and meninges (-Fig. 4 and 5). Immunohistochemistry: CD99 negative, BCL6 negative, BCL2 negative, AE1/AE3 negative, CD68 positive, kappa and lambda immunoglobulin chains positive, PAX positivity (25\%), KI67 focal positivity (10\%), CD1a negative, HHF35 negative, calretinin negative, and S100 with focal positivity $<2 \%$. Thus, the morphological aspects and the immunomarkers showed a limphohistiocytic lesion with a polytypic aspect compatible with a reactional lesion.

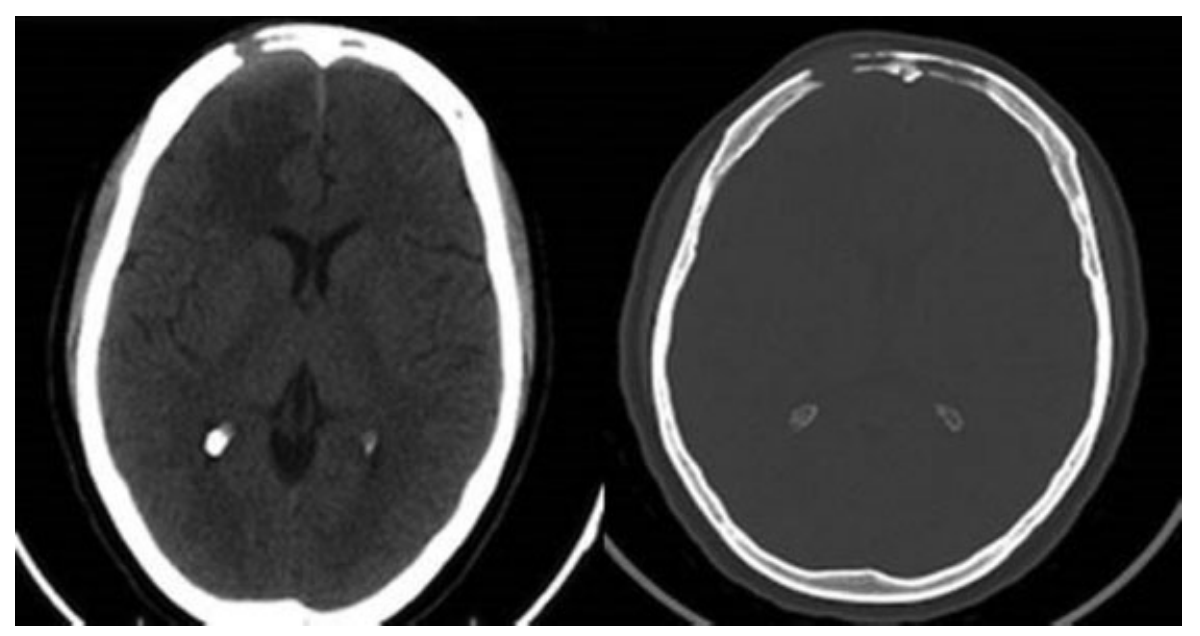

Fig. 1 A Skull CT (axial cut) shows a lytic lesion in the right frontal region and loss of cortical-subcortical differentiation. 


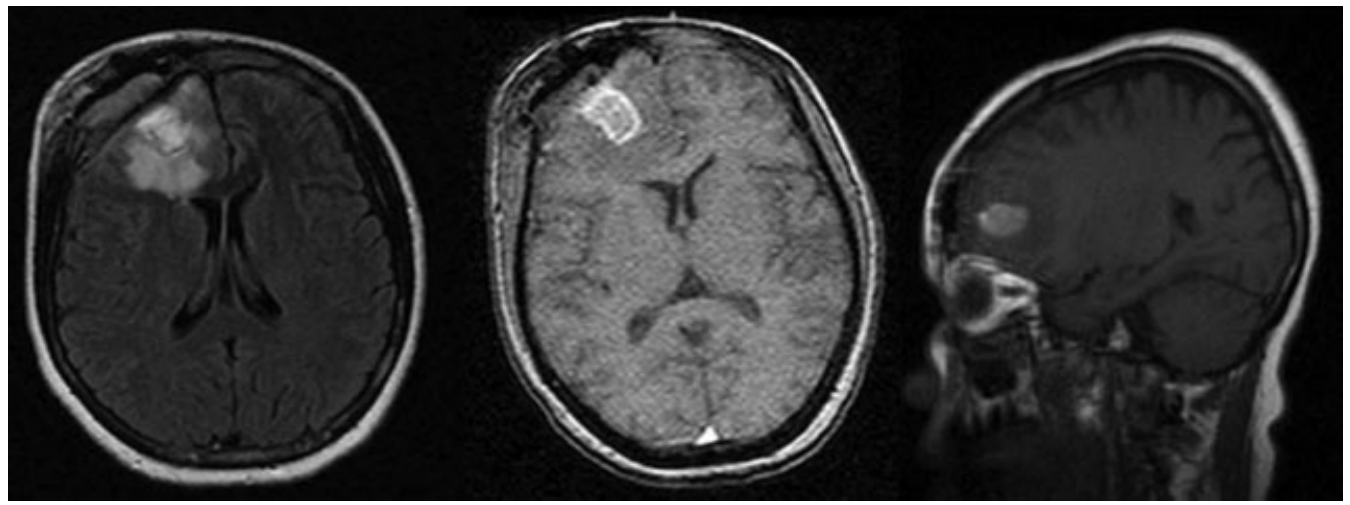

Fig. 2 An MRI shows the frontal and interhemispheric pachymeningeal thickening, which is predominantly right, associated with contrast enhancement. The presence of impairment of the cranial calotte and infiltration of the superior frontal gyrus and frontobasal can be observed.

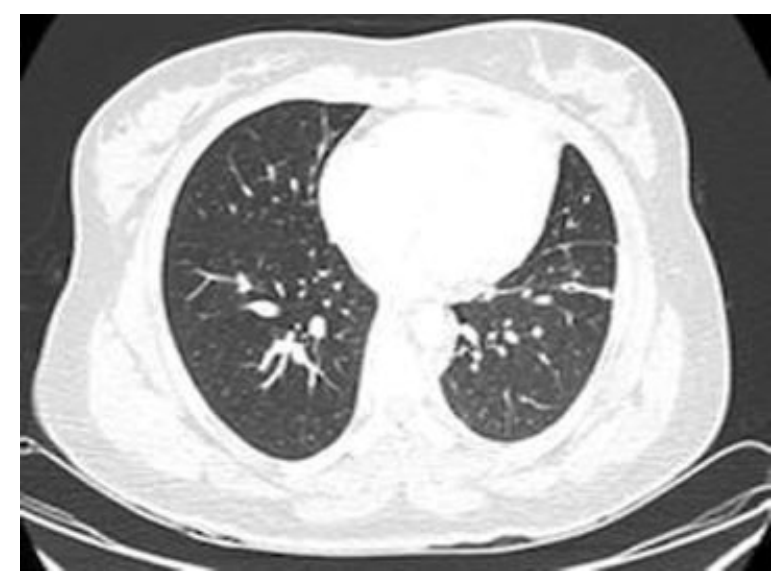

Fig. 3 Thoracic tomography (axial cut).

\section{Clinical Manifestations}

The symptoms of sarcoidosis depend on the affected organ, and the most nonspecific are fever, weight loss, night sweats, and fatigue. Neurological and cardiac symptoms are rare; however, when they are present, they indicate severe illness. ${ }^{4}$ The clinical presentation of neurosarcoidosis is usually optic neuropathy, facial paralysis, meningitis, chronic meningitis, diabetes insipidus, hydrocephalus, elevated intracranial pressure, spinal cord syndromes, vasculitis, cerebral infarction, dysfunctional hypothalamus, myelopathy, myopathy, peripheral neuropathy, and encephalitis ( - Table 1); the presentation of psychiatric symptoms and osseous involvement is rare. ${ }^{3,10-14}$

Cranial nerve alteration is present in $50-75 \%$ of the patients with neurosarcoidosis, and the most common affected nerves are, in descending order, cranial nerves VII, II and VIII. Cranial nerve VII is unilaterally affected in $65 \%$ of the cases, and bilaterally affected in $35 \% ;{ }^{7,15}$ cranial nerve II is affected in $5-25 \%$ of the patients. ${ }^{1}$ Bone involvement of the skull and bone involvement of the spine are rare; however, when the latter exists, it is located in the lower thoracic spine, or in the lumbar spine in most cases. ${ }^{16}$

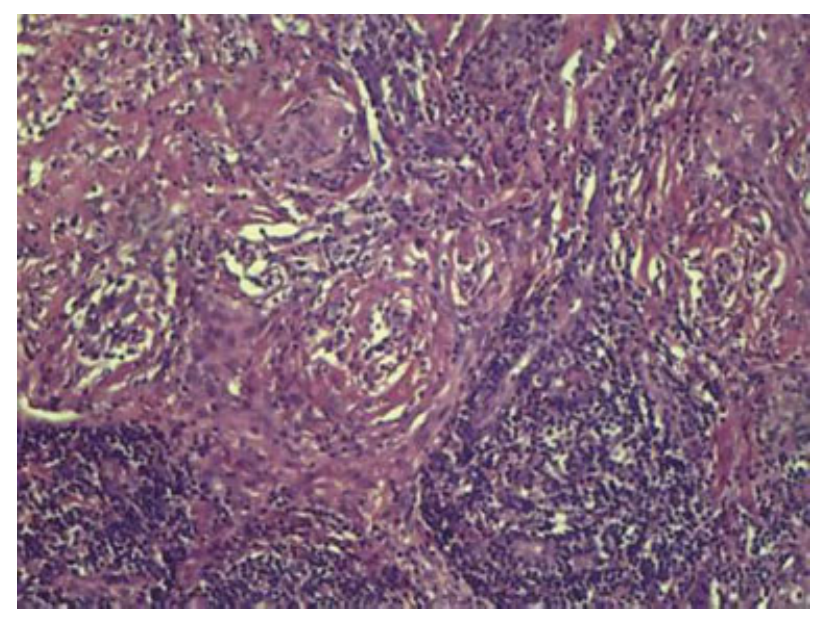

Fig. 4 Multiple non-caseating well-defined granulomas with fibrosis in the skull.

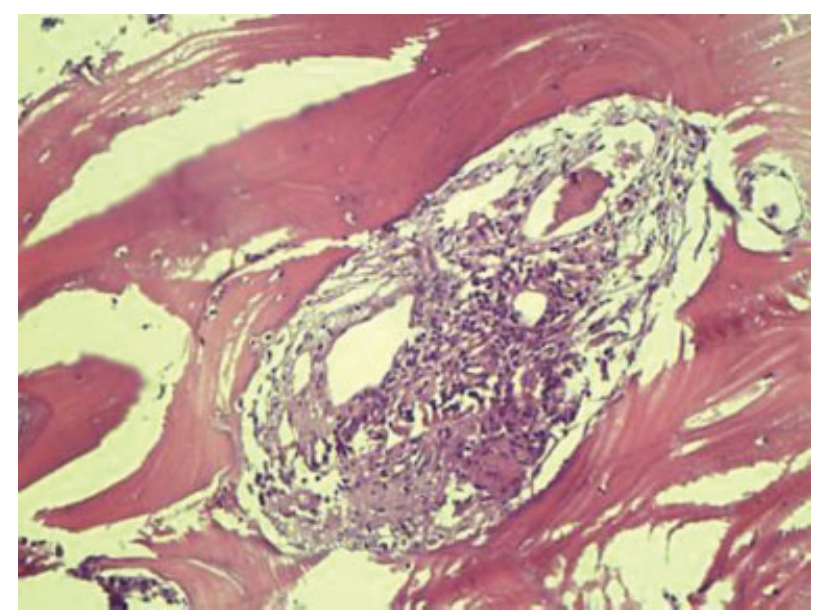

Fig. 5 Decalcified section of involved area of the skull (osseous tissue).

\section{Diagnosis}

The diagnosis is based on the clinical condition and radiological presentations; MRI with contrast is the chosen exam, and laboratory tests such as CSF analysis must be evaluated. 
Table 1 Percentages of neurological signs and symptoms

\begin{tabular}{|l|l|}
\hline Peripheral mononeuropathy & $69 \%$ \\
\hline Depression & $60-66 \%$ \\
\hline Stress & $55 \%$ \\
\hline Cranial nerve & $50 \%$ \\
\hline Headache & $17-48 \%$ \\
\hline Myelopathy & $16-43 \%$ \\
\hline Polyradiculoneuropathy & $39 \%$ \\
\hline Hydrocephalus & $5-38 \%$ \\
\hline Meningeal disease & $10-20 \%$ \\
\hline Seizures & $15 \%$ \\
\hline Osseous involvement & $13 \%$ \\
\hline
\end{tabular}

However, for the diagnostic confirmation, the exclusion of other inflammatory granulomatous diseases is necessary. ${ }^{17}$ The investigation with thorax imaging usually shows strong indications for the diagnosis and helps distinguish it from differential diagnoses (- Table 2 ). ${ }^{5}$

The Japanese Sarcoidosis Society and the Japanese Society of Respiratory Disease presented new diagnostic criteria for neurosarcoidosis that must consider two of six exams: bilateral pillar lymphadenopathy; abnormal uptake of 67Ga scintigraphy; alveolar lavage fluid examination; elevated serum angiotensin-converting enzyme (ACE); negative tuberculin reaction; and elevated serum or urinary calcium level. Besides these exams, there must be a compatible clinical history. ${ }^{18}$

The definitive diagnosis is made by biopsy of brain tissue, evidencing inflammatory tissue associated with non-caseating granuloma and systemic disease compatible with the diagnostic hypothesis; other possible causes must be excluded. ${ }^{19}$

\section{Discussion}

Pulmonary manifestations are present in $90 \%$ of the patients, but most of them are asymptomatic. Pulmonary involvement tends to be bilateral and asymmetrical, predominating in the upper lobes, and present atypical radiological aspects in $25 \%$ of the cases. ${ }^{20}$ Bronchiectasis is a typical, uncommon finding, mainly located in the lower lobes and unilateral, as presented

Table 2 Differential diagnoses

\begin{tabular}{|l|l|}
\hline $\begin{array}{l}\text { Involvement of brain } \\
\text { parenchyma }\end{array}$ & Meningeal involvement \\
\hline Multiple sclerosis & Bacterial meningitis \\
\hline Cerebral metastasis & Tuberculous meningitis \\
\hline Cerebral lymphoma & Carcinomatous meningitis \\
\hline Neurotuberculosis & Meningioma \\
\hline Fungal infections of the brain & Leukemic infiltration \\
\hline Low- and high-grade glioma & Meningeal plasmacytoma \\
\hline
\end{tabular}

in this case report. Pulmonary fibrosis is another finding that is present in bronchiectasis caused by sarcoidosis.

The psychiatric symptoms of apathy, agitation, delirium, hallucinations, irritability, lethargy, and depression improve with the use of corticosteroids. ${ }^{15}$ Involvement of the skull is uncommon; when it involves the bone in general, the incidence is between $1-13 \%,{ }^{16}$ and is usually asymptomatic, as in the case presented here.

Brain parenchyma involvement may present multiple lesions (35\%) or single lesions (10\%) analyzed in the MRI contrast phase. ${ }^{19}$ The MRI is the most sensitive test for the diagnosis of neurosarcoidosis, but a normal examination does not rule out the diagnosis, especially if the patient is under corticosteroid treatment. In MRI with contrast, leptomeningeal involvement is observed in $40 \%$ of the cases, and it is more common in the frontobasal and suprasellar regions. ${ }^{5,19}$ The CSF may present hyperproteinemia in $73 \%$ of the patients and lymphocytosis in 55\%; normal CSF is uncommon. ${ }^{2,5,11}$

The non-caseating granuloma of sarcoidosis has immunological origin, and is formed by giant cells and epithelioid cells (consisting of histiocytes modified by $\mathrm{T}$ lymphocytes). The presence of giant and epithelioid cells is a sign of high cellular turnover. Granulomas are uniform, and have as their components histiocytes of broad and eosinophilic cytoplasm, oval or twisted vesicular nucleus, and prominent nucleoli. $4,13,21$ Fibrinoid necrosis is present in 35\% of the cases. $^{21}$

As radiological differential diagnoses we could mention glioblastoma, lymphoma, abscess, metastasis and even variations of multiple sclerosis. Nevertheless, among the lesions that can affect the skull and brain, we can list metastasis, lymphoma; primary skull tumors, such as chondrosarcoma, chordoma, esthesioneuroblastoma and malignant histiocytic tumor; and tumor-like lesions, such as fibrous dysplasia eosinophilic granuloma. ${ }^{22,23}$

The treatment is clinical, with prednisolone $40-80 \mathrm{mg}$ (oral administration) at first; as an alternative for more severe cases, intravenous methylprednisolone can be used. ${ }^{9}$ In case of refractoriness, there are options such as: mycophenolate, methotrexate, cyclophosphamide, azathioprine, chloroquine and tumor necrosis factor alpha (TNF- $\alpha) ;^{7}$ another alternative is radiotherapy. ${ }^{15}$ In cases of systemic suspicion of neurosarcoidosis, stereotactic biopsy can be used for confirmation. $^{7}$

\section{Conclusion}

Neurosarcoidosis is a serious and rare condition. The discussed case presented a single extracranial alteration: asymptomatic pulmonary bronchiectasis located in an atypical region. The intracranial manifestations presented were: lytic bone lesion and psychiatric symptoms (rare occurrence in the literature). Thus, this case may contribute to the diagnosis of other cases with rare presentation.

Disclosure - Conflicts of Interest

Authors declare no conflicts of interest. 


\section{References}

1 Vinas FC, Rengachary S. Diagnosis and management of neurosarcoidosis. J Clin Neurosci 2001;8(06):505-513

2 Agnihotri SP, Singhal T, Stern BJ, Cho TA. Neurosarcoidosis. Semin Neurol 2014;34(04):386-394

3 Celebi A, Deveci S, Gursoy AE, Kolukisa M. A case of isolated neurosarcoidosis associated with psychosis. Neurosciences (Riyadh) 2013;18(01):70-73

4 Daldon PEC, Arruda LHF. Noninfectious granulomas: sarcoidosis. An Bras Dermatol 2007;82(06):559-571

5 Nozaki K, Judson MA. Neurosarcoidosis: Clinical manifestations, diagnosis and treatment. Presse Med 2012;41(6 Pt 2):e331-e348

6 Rybicki BA, Iannuzzi MC. Epidemiology of sarcoidosis: recent advances and future prospects. Semin Respir Crit Care Med 2007;28(01):22-35

7 Terushkin V, Stern BJ, Judson MA, et al. Neurosarcoidosis: presentations and management. Neurologist 2010;16(01):2-15

8 Gonzalez-Granado LI. Reply: Presentations and outcomes of neurosarcoidosis: a study of 54 cases. QJM 2009;102(12):889-891

9 Nowak DA, Widenka DC. Neurosarcoidosis: a review of its intracranial manifestation. J Neurol 2001;248(05):363-372

10 Radwan W, Lucke-Wold B, Robadi IA, Gyuri K, Roberts T, Bathia S. Neurosarcoidosis: unsual presentations and considerations for diagnosis and management. Postgrad Med J 2017;93:401-405

11 Besur S, Bishnoi R, Talluri SK. Neurosarcoidosis: rare initial presentation with seizures and delirium. QJM 2011;104(09):801-803

12 Carlson ML, White JR Jr, Espahbodi M, et al. Cranial base manifestations of neurosarcoidosis: a review of 305 patients. Otol Neurotol 2015;36(01):156-166
13 Manz HJ. Pathobiology of neurosarcoidosis and clinicopathologic correlation. Can J Neurol Sci 1983;10(01):50-55

14 Skowasch D, Pabst S, Wilhelm K, Grohé C. [Diabetes insipidus due to neurosarcoidosis]. Pneumologie 2011;65(08):496-497

15 Joseph FG, Scolding NJ. Sarcoidosis of the nervous system. Pract Neurol 2007;7(04):234-244

16 Smith JK, Matheus MG, Castillo M. Imaging manifestations of neurosarcoidosis. AJR Am J Roentgenol 2004;182(02):289-295

17 Stjepanović MI, Vucinić VM, Jovanović D, Mijajlović M, Trifunović VS, Stjepanović MM. Diagnosis of neurosarcoidosis-necessity of biopsy. Med Pregl 2014;67(3-4):97-99

18 Sakuta M, Kumamoto T, Iizuka T, Nishiyama K, Oritsu M. [Diagnostic criteria of neurosarcoidosis]. No To Shinkei 2006;58(06): 471-476

19 Bathla G, Singh AK, Policeni B, Agarwal A, Case B. Imaging of neurosarcoidosis: common, uncommon, and rare. Clin Radiol 2016;71(01):96-106

20 Nobrega BB, Meirellis GSP, Szarf G, Jasinowodolinski D, Kavakama JI. Pulmonary sarcoidosis: High-resolution computed tomography findings. J Bras Pneumol 2006;31(03):254-260

21 Mitchell DN, Scadding JG, Heard BE, Hinson KF. Sarcoidosis: histopathological definition and clinical diagnosis. J Clin Pathol 1977;30(05):395-408

22 Ciarpaglini R, Otten P. Primary cranial vault lymphoma with brain infiltration: case report and review of the literature. $\mathrm{Br} \mathrm{J}$ Neurosurg 2012;26(05):756-758

23 Stark AM, Eichmann T, Mehdorn HM. Skull metastases: clinical features, differential diagnosis, and review of the literature. Surg Neurol 2003;60(03):219-225, discussion 225-226 